\title{
ROLE OF DISPERSAL TIMING AND FREQUENCY IN ANNUAL GRASS-INVADED GREAT BASIN ECOSYSTEMS: HOW MODIFYING SEEDING STRATEGIES INCREASES RESTORATION SUCCESS
}

\author{
Merilynn C. Schantz ${ }^{1}$, Roger L. Sheley² ${ }^{2}$ Jeremy J. James ${ }^{3}$, and Erik P. Hamerlynck²
}

\begin{abstract}
Seed dispersal dynamics strongly affect plant community assembly in restored annual grass-infested ecosystems. Modifying perennial grass seeding rates and frequency may increase perennial grass establishment, yet these impacts have not yet been quantified. To assess these effects, we established a field experiment consisting of 288 plots $\left(1 \mathrm{~m}^{2}\right)$ in an eastern Oregon annual grass-dominated shrubsteppe ecosystem. In this study, the amount, timing, and frequency of perennial grass seeding events, soil moisture availability, and annual grass seed bank density were manipulated. We found that more frequent perennial grass seeding events combined with high perennial grass seeding rates produced the highest perennial grass density and biomass 2 years following seeding. However, we also found that if annual grass seed density was 1500 seeds $\cdot \mathrm{m}^{-2}$ or higher, perennial grass density and biomass decreased, regardless of seeding strategy. Because of this finding, it appears that a threshold is crossed between 150 and 1500 annual grass seeds $\cdot \mathrm{m}^{-2}$. Adding water in the first growing season initially facilitated perennial grass establishment but only produced higher perennial grass density following the second growing season when annual grass density was lowest. Assessing the existing annual grass seed bank prior to seeding can likely forecast restoration outcomes because high annual grass seed densities likely interfere with and reduce perennial grass recruitment. In addition, if annual grass seeding density is 1500 seeds $\cdot \mathrm{m}^{-2}$ or lower, modifying the temporal patterns of perennial grass seed arrival will increase the likelihood that a perennial grass seed finds a safe-site.
\end{abstract}

Resumen.-La dinámica de dispersión de semillas afecta considerablemente el ensamble de la comunidad vegetal en los ecosistemas restaurados e infestados por pasto anual. La modificación del ritmo y la frecuencia de siembra del pasto perenne pueden incrementar el restablecimiento del mismo; sin embargo, el impacto aún no ha sido cuantificado. Para evaluar tales efectos, establecimos un experimento de campo que consistió de 288 parcelas $\left(1 \mathrm{~m}^{2}\right)$ en un ecosistema de estepa herbácea, al este de Oregon, dominado por un pasto anual. En este estudio manipulamos la cantidad, el ritmo y la frecuencia de eventos de siembra de pasto perenne, así como la disponibilidad de la humedad del suelo y la densidad del banco de semillas de siembra de pasto anual. Encontramos que la mayoría de los eventos de siembra de pasto perenne, en conjunto con tasas altas de siembra de tales pastos, producen la densidad más alta de pasto perenne y de biomasa dos años después de la siembra. Sin embargo, también encontramos que si la densidad de semillas de pasto anual era de 1500 semillas por $\mathrm{m}^{2}$ o mayor, la densidad del pasto perenne y su biomasa disminuía independientemente de la estrategia de la siembra. Debido a este hallazgo, parece que el umbral se cruza entre las 150-1500 semillas de pasto anual por $\mathrm{m}^{2}$. Agregar agua durante la primera temporada de crecimiento inicialmente facilitó el establecimiento del pasto perenne, pero sólo produjo una mayor densidad del mismo después de la segunda temporada de crecimiento, cuando la densidad del pasto anual estuvo en su nivel más bajo. La evaluación del banco de semillas de pasto anual existente antes de la siembra puede ayudar a estimar los resultados de restauración, debido a que las altas densidades de siembra de pasto anual probablemente interfieran y reduzcan el reclutamiento de pasto perenne. Adicionalmente, si la densidad de semillas de pasto anual es de 1500 semillas por $\mathrm{m}^{2}$ o menor, modificar los patrones temporales de siembra de pasto perenne puede incrementar la probabilidad de que una semilla de pasto perenne encuentre un sitio seguro.

Invasive annual grasses threaten a number of perennial-dominated dryland systems across the globe (Seastedt and Pyšek 2011). Seeding can accelerate native plant recovery and stabilize native populations in highly degraded and annual grass-invaded areas (Seabloom et al. 2003). However, restoring stable native plant communities into invaded plant communities typically has low success rates (Sheley and James 2014). A good example is found in seeding native perennial grasses into annual grass-invaded shrubsteppe ecosystems (Cox and Allen 2008). Native perennial grasses have low recruitment rates within shrubsteppe ecosystems, especially when invasive annual grasses are present (James et al. 2012), primarily because annual grasses begin growth earlier than native perennial grasses

\footnotetext{
${ }^{1}$ Department of Animal and Rangeland Sciences, Oregon State University, Corvallis, OR 97332. E-mail: merilynn.schantz@ars.usda.gov

${ }^{2}$ United States Department of Agriculture, Agricultural Research Service, Burns, OR 97720.

${ }^{3}$ Sierra Foothills Research and Extension Center, University of California Division of Agriculture and Natural Resources, Browns Valley, CA 95918.
} 
(Abraham et al. 2009). Moreover, annual grasses produce copious amounts of seeds in the first growing season (Kulpa et al. 2012), whereas perennial grasses develop slowly from seed, generally not reaching reproductive maturity until the second growing season (Montoya et al. 2012). Because perennial grass recruitment is limited by the temporal growth and the high propagule pressure of annual grasses (Orrock and Christopher 2010), the continued dominance of annual grasses is probable without active management intervention.

Seed dispersal can be a major driving mechanism of plant community assembly, especially during invasion and restoration because dispersal controls recruitment of newly arriving species by influencing safe-site occupation (Satterthwaite 2007). Safe-sites, or realized niches, support diverse plant populations and these sites provide conditions suitable for seedling germination and establishment (Grubb 1977). In addition, safe-sites interact with seed availability to largely affect plant community assembly (Doll et al. 2011). In an earlier experiment, we measured the effects of annual grass dispersal dynamics on plant community assembly and found that perennial grasses had higher establishment when they were seeded with annual grasses in autumn compared to delaying annual grass seeding until spring (Schantz et al. 2015). From this previous study, we concluded that perennial grasses had greater recruitment when seeded with annual grasses in autumn because annual grasses have high winter mortality in arid Great Basin ecosystems. Consequently, because earlier seeded species have greater access to available resources (Doll et al. 2011), increasing the seeding frequency to autumn and spring may increase perennial grass seedling recruitment.

Here, we present the results of a multiyear study where we sought to quantify how the amount, timing, and frequency of perennial grass seeding affects the temporal trajectories of annual and perennial grass seedling emergence, and shapes plant community composition and biomass 2 years following seeding. In addition, we sought to quantify how these dynamics are modified by soil water availability and annual grass seed bank density. To accomplish these objectives we experimentally varied seeding rates of desired native species across 3 distinct seed timing regimes: (1) seeding exclusively in the autumn, (2) seeding exclusively in the spring, or (3) increasing seeding frequency by evenly splitting seeding between spring and autumn. These perennial grass seeding regimes were applied into plots with varying invasive annual autumn seeding rates and water availability. Based on the fact that under drier conditions invasive annual grasses are better able to recruit from their extensive seed banks than native perennial grasses (Humphrey and Schupp 2001), and frequently initiate seedling germination and emergence earlier in the spring (Abraham et al. 2009), annual grass interference will likely be high and safe-site availability will be low during springtime (Evans and Young 1972). In addition, because annual grasses have high winter mortality (James et al. 2012), perennial grasses may be better able to fill realized niches when seeded in the spring (Fig. 1). However, spring-seeded perennial grasses can have delayed growth due to the lower number of growing days and because many perennial grass seeds require cold stratification (Walck et al. 2011). Thus, increasing perennial grass seeding frequency to fall and spring should increase the likelihood that perennial seeds find the realized niche in annual grass-dominated systems. For this study, we specifically hypothesized that (1) perennial grass seed dispersal split between the autumn and spring would result in higher perennial grass density and biomass compared to seeding native grasses exclusively in either period; (2) perennial grass density and biomass in seasonally split applications would be higher when perennial propagule pressure was high and annual grass propagule pressure was low; and (3) adding water would increase perennial grass density and biomass, especially in plots with seasonally split seeding and high perennial grass propagule pressure. Identifying the relative effect of propagule pressure and dispersal timing and frequency on community assembly should allow ecologists to better plan successful restoration projects in annual grass-invaded shrubsteppe ecosystems.

\section{Methods}

The study site was located on $2881-\mathrm{m}^{2}$ plots in low-elevation (1033 m) shrubsteppe dominated by annual grasses located approximately $5 \mathrm{~km}$ south of Juntura, Malheur County, Oregon (UTM: Zone 11, 410178, 


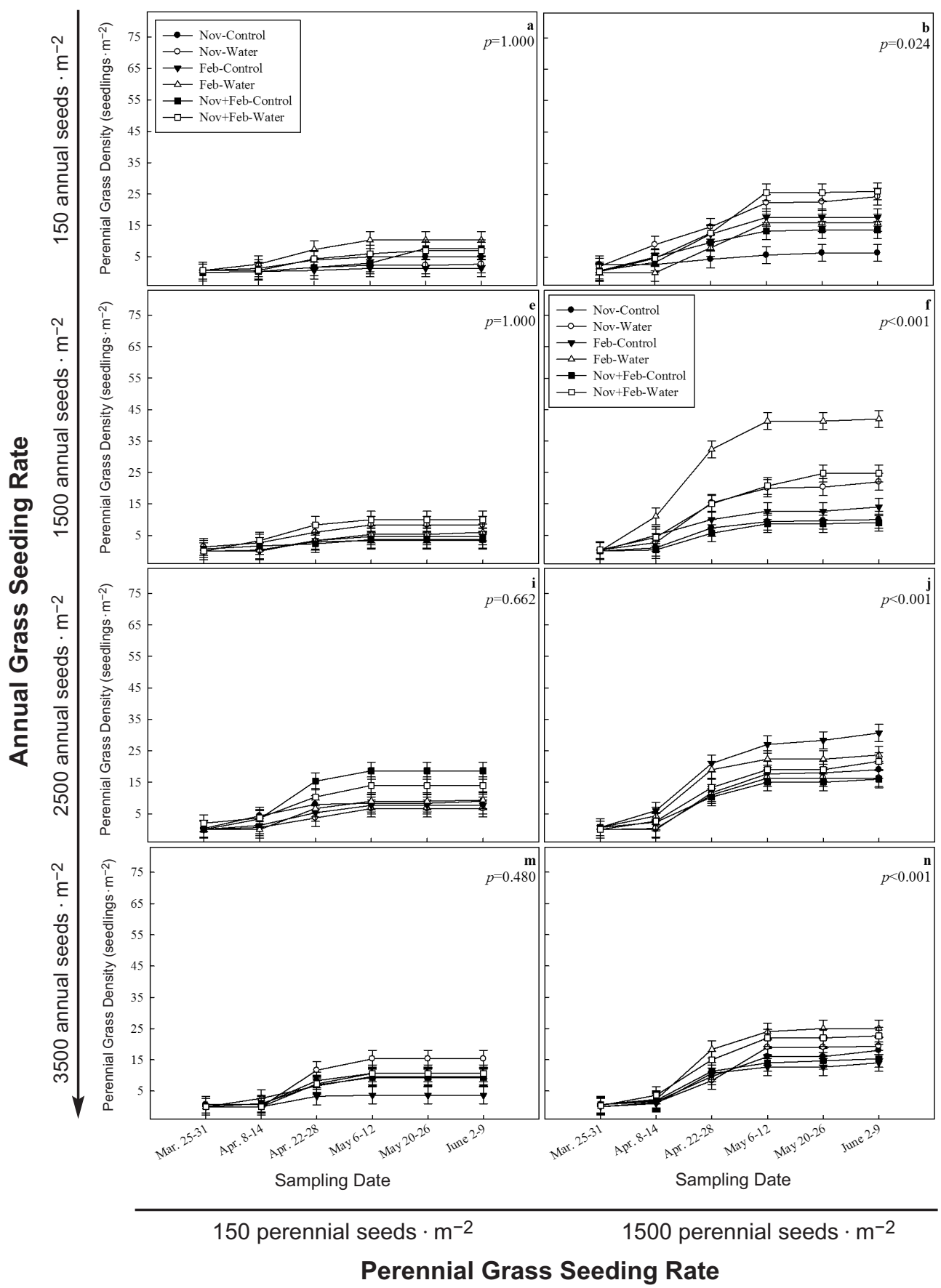

Fig. 1. Representation of the differences in LS means $( \pm 1 \mathrm{SE})$ in perennial grass seedling density (seedlings $\left.\cdot \mathrm{m}^{-2}\right)$ at $[\mathrm{Nov}+\mathrm{Feb}]$ ) and watering treatments (water or no water) interactions for each annual and perennial grass propagule along the $x$-axis and annual grass seeding rate $\left(\right.$ seeds $\cdot \mathrm{m}^{-2}$ ) increases from top to bottom along the $y$-axis. Each panel perennial grass seeding rate combination, and $P$ values on each panel represent differences at these given annual and bottom to top) and sampling time (25 March-9 June) along the $x$-axis (increases from left to right). 


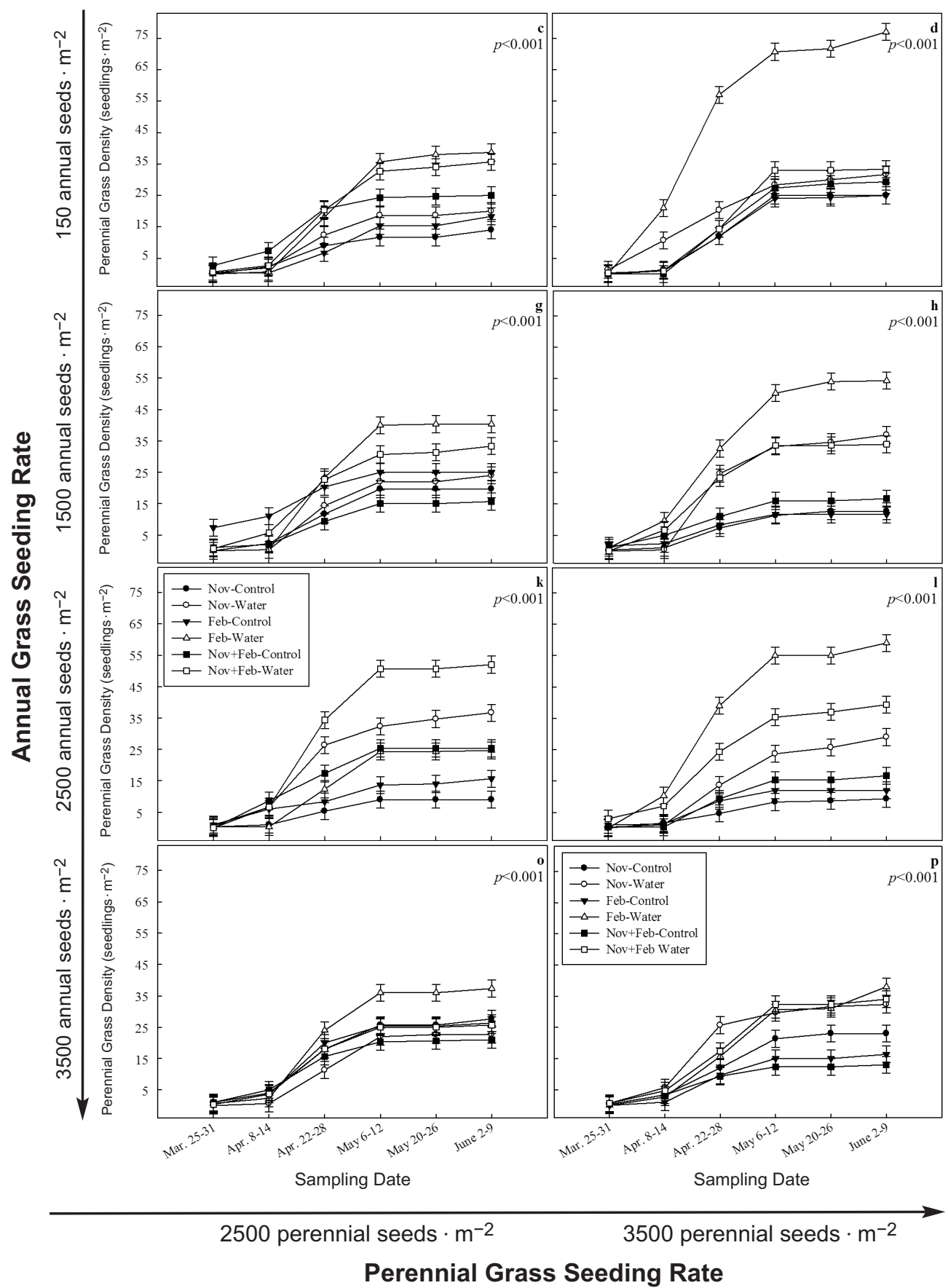

6 sampling times in the first growing season (2012) by seeding time (autumn [Nov], spring [Feb], or autumn and spring pressure $\left(150,1500,2500\right.$, or 3500 seeds $\left.\cdot \mathrm{m}^{-2}\right)$. Perennial grass seeding rate (seeds $\cdot \mathrm{m}^{-2}$ ) increases from left to right $(\mathrm{a}-\mathrm{p})$ is graphed using the LS means $( \pm 1 \mathrm{SE})$ of perennial grass density (seedlings $\cdot \mathrm{m}^{-2}$ ) for the given annual and perennial grass seeding rates. Each panel has perennial grass density (seedlings $\cdot \mathrm{m}^{-2}$ ) along the $y$-axis (increases from 
4840910). This site has a very slight slope facing southwesterly and is devoid of sagebrush. Current vegetation structure is a near monoculture of the exotic annual grass medusahead (Taeniatherum caput-medusae [L.] Nevski) growing in association with cheatgrass (Bromus tectorum L.), Sandberg bluegrass (Poa secunda J. Presl), bottlebrush squirreltail (Elymus elymoides [Raf.] Swezey), whitetop (Cardaria draba [L.] Desv.), and morning glory (Ipomoea eriocarpa $\mathrm{R}$. Br.). Soils are a sandy-loam within the Bogusrim series (fine, smectitic, mesic abruptic Xeric Argidurids) that receive $257 \mathrm{~mm}$ average precipitation per year with a bimodal distribution peaking in the winter and spring.

Average precipitation $(\mathrm{cm})$, and temperature $\left({ }^{\circ} \mathrm{C}\right)$ were recorded daily from November 2011 to June 2013 using a HOBO rain gauge smart sensor that was connected to a $\mathrm{HOBO}$ weather station and mounted approximately $3 \mathrm{~m}$ from the soil surface inside of a HOBO solar shield (Onset Comp. Inc., Cape Cod, MA). Long-term (1963-1996) daily average precipitation and temperature data from Juntura, Oregon, were obtained from the Western Regional Climate Center (WRCC 2013). Volumetric soil water content $(\%)$ and soil temperature $\left({ }^{\circ} \mathrm{C}\right)$ at $5 \mathrm{~cm}$ were monitored using Decagon 5TM soil moisture sensors (Decagon Devices Inc., Pullman, WA) located within the treatment plots from November 2011 to June 2013.

\section{Model System}

To test how seeding strategies affect species density through their life history, we used a model system consisting of the invasive annual grasses cheatgrass and medusahead (50:50 mixture) as the invaders. The desired native system was represented by the 4 perennial grasses Anatone bluebunch wheatgrass (Pseudoroegneria spicata [Pursh] A. Löve), bottlebrush squirreltail, Mountain Home Sandberg bluegrass, and Thurber's needlegrass (Achnatherum thurberianum [Piper] Barkworth) seeded in equal proportions. Annual grass seeds were collected locally, by hand, from Harney Co., Oregon, whereas bottlebrush squirreltail, Sandberg bluegrass, and bluebunch wheatgrass were purchased from Granite Seed Co., Lehi, Utah, in 2011, and Thurber's needlegrass was purchased from BFI Native Seeds Co., Moses Lake, Washington, in 2010. Each plot received $100 \%$-pure live seeds per plot by calculating the weight of each species necessary to achieve the desired seeding rate and adding these seeds to each $1-\mathrm{m}^{2}$ plot.

\section{Propagule Pressure and Dispersal Timing and Frequency}

In September 2011, prior to the initiation of the study, the site was sprayed with 3.36 $\mathrm{L} \cdot \mathrm{ha}^{-1}$ of glyphosate [N-(phosphonomethyl) glycine] and tilled to about $100 \mathrm{~mm}$ to remove any existing vegetation. Densities and proportions of annual grasses and perennial grasses were arranged to provide 4 addition-series matrices (Radosevich 1987). A factorial design was used with 4 seeding densities of annual grasses $\left(150,1500,2500\right.$, or 3500 seeds $\left.\cdot \mathrm{m}^{-2}\right)$ and 4 seeding densities of perennial grasses $\left(150,1500,2500\right.$, or 3500 seeds $\left.\cdot \mathrm{m}^{-2}\right)$. This produced the following seeding density ratios (annuals:perennials) in each matrix: 150:150, 150:1500, 150:2500, 150:3500, 1500:150, 1500: 1500, 1500:2500, 1500:3500, 2500:150, 2500: 1500, 2500:2500, 2500:3500, 3500:150, 3500: 1500, 3500:2500, and 3500:3500 seeds $\cdot \mathrm{m}^{-2}$. Annual grass seeds were sown exclusively in the autumn (November 2011), whereas perennial grasses were either sown in autumn only, spring only (February 2012), or seasonally split (even seeding of $50 \%$ of the allotted seeds in autumn and the remaining 50\% in spring). Half of the plots of each seeding regime were randomly selected for a watering treatment (see below) to complete the treatment matrix. Each matrix was replicated 3 times in a completely randomized design, yielding $2881-\mathrm{m}^{2}$ plots (16 seeding levels $\times 3$ seeding timings $\times$ 2 watering treatments $\times 3$ replications $=288$ plots; Appendix 1).

Seeding was achieved by hand broadcasting seeds onto the soil surface of $1-\mathrm{m}^{2}$ plots and covering seeds with $2 \mathrm{~cm}$ of sifted weedfree topsoil collected from the site. Watering was administered weekly during the growing season in year one (1 March-30 May 2012) using watering cans to evenly distribute water on each water-added treatment plot. Water was added at twice the long-term monthly precipitation average (March-May), which varied from 2.05-2.61 $\mathrm{L}$ added per plot per month (Appendix 2). Watering only occurred during the first growing season, 2012, to identify how water availability during the first growing season affected plant performance in subsequent years. 


\section{Sampling and Measurements}

Plant density was counted within the center $0.5 \mathrm{~m}^{2}$ of the plot for perennials and the center $0.25 \mathrm{~m}^{2}$ for annuals biweekly during the first growing season (25 March-9 June 2012 ) yielding 6 sampling times $(288$ plots $\times 6$ sampling times $=1728$ measurements). Because of the high density of annual grasses and the difficulty of counting all annual and perennial grasses within each plot, the measurement area for annual grass density was lower than that for perennial grasses. Plants were individually marked, biweekly, with toothpicks as they emerged. At peak standing crop on year 2 (3-14 June 2013), final density was counted, all plants were clipped to ground level, sorted by species, dried at $60{ }^{\circ} \mathrm{C}$, and weighed to determine individual plant biomass $\left(\mathrm{g} \cdot\right.$ plant $\left.^{-1}\right)$.

\section{Statistical Analysis}

All data were pooled by annual and perennial grasses and analyzed for normality of distribution and homogeneity of variance using Shapiro-Wilk and Levene's tests, respectively (SAS 2012). Annual grass emergent coleoptile density, established final grass density, and biomass were normally distributed. However, these variables from perennial grasses showed distinct right-skewing. Log, square root, inverse square root, $\log +1$, and square root +1 transformations were used but did not improve data distribution or model $t$. Thus, all models were generated from nontransformed data for perennial species.

To test for differences in the seasonal emergence of perennial and annual grasses, emergent coleoptile seedling densities were analyzed using a repeated-measures analysis of variance (RM-ANOVA; SAS 2012). In this model, main effects tested were perennial grass dispersal time (autumn, spring, and split seeding), watering (control vs. water added), annual grass seeding rate $(150,1500,2500$, or 3500 seeds . $\left.\mathrm{m}^{-2}\right)$, perennial grass seeding rate $(150,1500$, 2500 , or 3500 seeds $\cdot \mathrm{m}^{-2}$ ), and sampling time (biweekly yielding 1728 total samples). A mixed-model ANOVA was also used to test differences in perennial grass dispersal time, watering, annual grass seeding rate, and perennial grass seeding rate on final plant density and biomass per plot (SAS 2012). In both the coleoptile emergence and final density and biomass models, the random factor was replication, means were separated using the slice procedure (Schabenberger 2013), F test results with an associated $P$ value of $\leq 0.05$ were considered significant, and least squared means are reported for significant results.

\section{RESUlTS}

\section{Environmental Conditions}

Temperature was consistent with long-term averages, whereas precipitation was lower than the 30-year mean in the summer months and average throughout the rest of the year (Appendix 2). Volumetric water content and soil temperature at $5 \mathrm{~cm}$ were not different between the water added and ambient water plots (Appendix 3). Volumetric water content fluctuated from a high of about 25\% from November to April to a low of about $10 \%$ from May to October (Appendix 3A, B). Soil temperature at $5 \mathrm{~cm}$ fluctuated similarly to air temperature, but was generally $5{ }^{\circ} \mathrm{C}$ higher than air temperature throughout the study period (Appendix 3C, D).

\section{Seedling Density}

When perennial grass seeding rates were 150 seeds $\cdot \mathrm{m}^{-2}$, all treatments produced similarly low perennial grass density (Fig. la, $\mathrm{e}, \mathrm{i}, \mathrm{m})$. Higher perennial grass seeding rates produced higher perennial grass seedling density (Fig. ld, f, g, h, k, l, o, p; $F_{3,144}=$ 33.16, $P<0.001)$. Pooled across watering and seeding rates, seeding perennial grasses in spring or in a split seeding regime yielded higher perennial grass density than seeding perennial grasses in autumn (Fig. $1 \mathrm{j}, \mathrm{k}, \mathrm{l}, \mathrm{o} ; F_{2,48}$ $=4.12, P=0.022)$. When water was added, perennial grass seeding density was higher across all seeding treatments (Fig. $\mathrm{lb}-\mathrm{d}, \mathrm{f}-\mathrm{h}, \mathrm{k}, \mathrm{l}$, $\left.\mathrm{n}-\mathrm{p} ; F_{1,12}=41.17, P<0.001\right)$. However, the lack of a significant seeding rate $\times$ watering treatment interaction showed that adding water similarly affected perennial grass density regardless of annual or perennial grass seeding rates (Fig. $1 \mathrm{i}, \mathrm{j}, \mathrm{n}-\mathrm{p} ; F_{9,44}=0.91, P=$ $0.521)$. Across all seeding treatments, perennial grass seedling density increased from about mid- to late April to mid-May (Fig. lb-d, $\left.\mathrm{f}-\mathrm{h}, \mathrm{j}-\mathrm{l}, \mathrm{n}-\mathrm{p} ; F_{5,12}=43.39, P<0.001\right)$.

Annual grass density varied significantly by annual $\left(F_{3,144}=21.9, P<0.001\right)$ and perennial grass seeding rates (Fig. $2 \mathrm{f}-\mathrm{h}, \mathrm{j}-\mathrm{p} ; F_{3,144}=5.93$, 


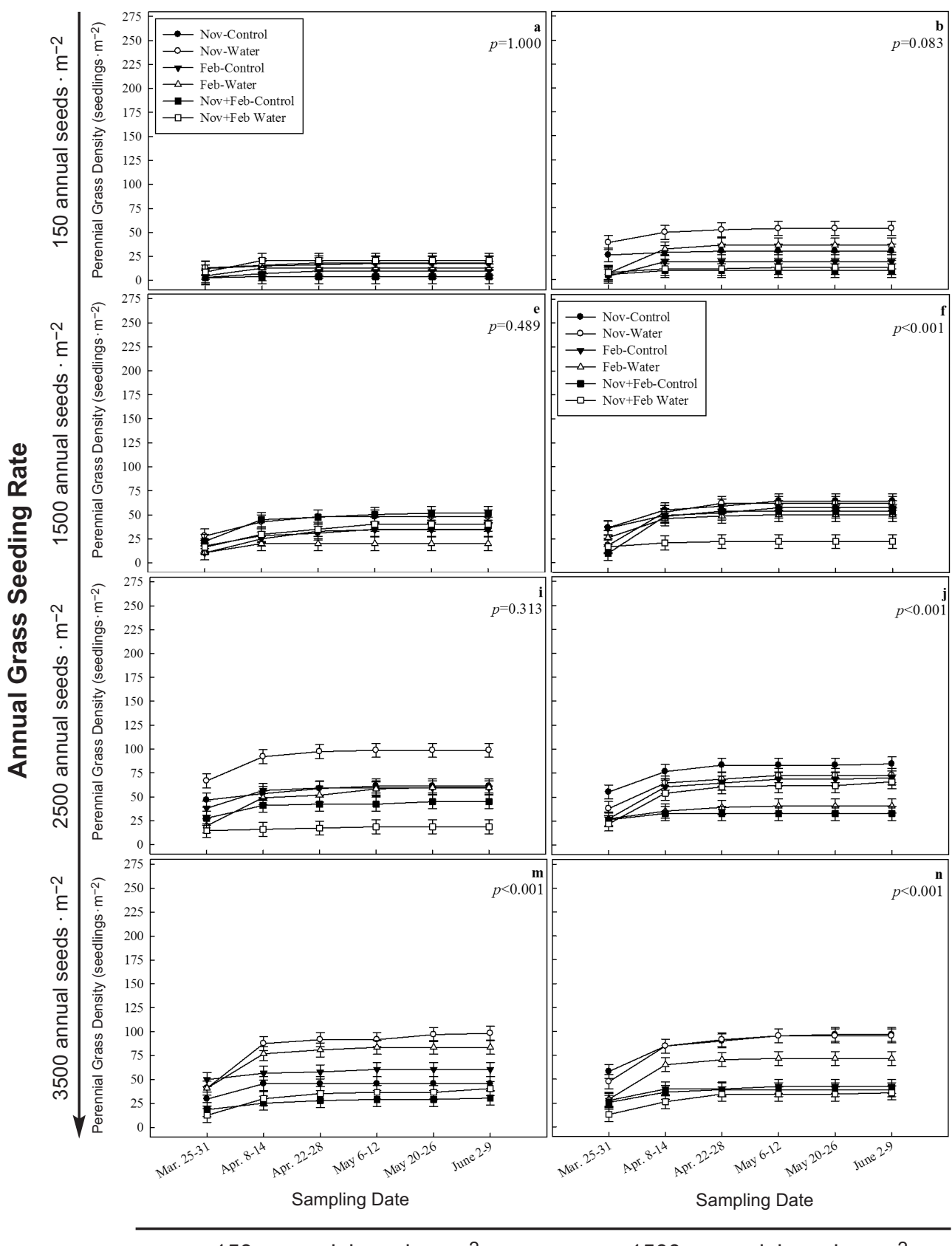

150 perennial seeds $\cdot \mathrm{m}^{-2}$

1500 perennial seeds $\cdot \mathrm{m}^{-2}$

Perennial Grass Seeding Rate

Fig. 2. Representation of the differences in LS means ( $\pm 1 \mathrm{SE})$ in annual grass seedling density (seedlings $\cdot \mathrm{m}^{-2}$ ) and spring $[\mathrm{Nov}+\mathrm{Feb}]$ ) and watering treatments (water or no water) interactions for each annual and perennial increases from left to right along the $x$-axis, and annual grass seeding rate (seeds $\cdot \mathrm{m}^{-2}$ ) increases from top to (seedlings $\cdot \mathrm{m}^{-2}$ ) for the given annual and perennial grass seeding rate combination, and $P$ values on each panel density (seedlings $\cdot \mathrm{m}^{-2}$ ) along the $y$-axis (increases from bottom to top) and sampling time (25 March-9 June) along the 


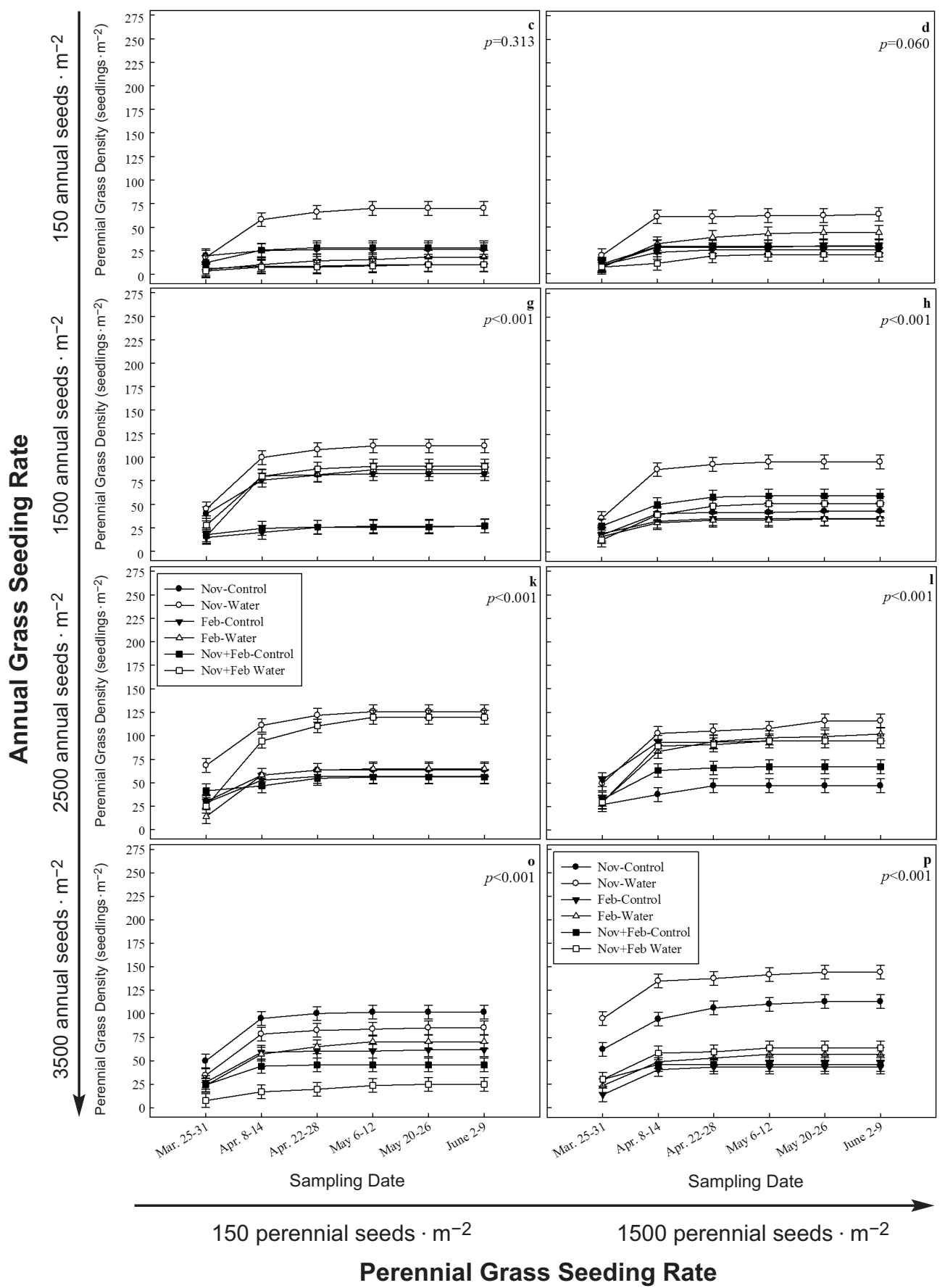

at 6 sampling times in the first growing season (2012) by seeding time (autumn [Nov], spring [Feb], or autumn grass propagule pressure $\left(150,1500,2500\right.$, or 3500 seeds $\left.\cdot \mathrm{m}^{-2}\right)$. Perennial grass seeding rate $\left(\mathrm{seeds}^{\cdot} \mathrm{m}^{-2}\right)$ bottom along the $y$-axis. Each panel $(a-p)$ is graphed using the LS means $( \pm 1 \mathrm{SE})$ of annual grass density represent differences at these given annual and perennial grass seeding rates. Each panel has perennial grass $x$-axis (increases from left to right). 
TABLE 1. ANOVA $F$ test results for perennial seeding timing (spring, autumn, and split), watering (control and water added), and annual and perennial seeding rate on the final density and biomass of annual and perennial grasses obtained in $2013(n=288, \mathrm{df}=190)$. Den-df refers to the denominator degrees of freedom. Bolded $F$ test results are significant.

\begin{tabular}{|c|c|c|c|c|c|}
\hline \multirow[b]{3}{*}{ Effects and interactions } & \multirow[b]{3}{*}{ Den-df } & \multicolumn{4}{|c|}{$F$ value } \\
\hline & & \multicolumn{2}{|c|}{ Perennial grass } & \multicolumn{2}{|c|}{ Annual grass } \\
\hline & & Density & Biomass & Density & Biomass \\
\hline Seeding time (Timing) & 2 & $10.51 * *$ & $5.36^{* *}$ & $10.26^{* * *}$ & $7.53 * *$ \\
\hline Water & 1 & $29.56 * *$ & 0.14 & 0.14 & $13.96 * *$ \\
\hline Timing + Water & 2 & $3.27 *$ & 0.13 & 1.14 & 1.34 \\
\hline Annual seeding rate (Annual) & 3 & $13.68 * *$ & $5.23^{* *}$ & $29.44^{* *}$ & $19.22 * *$ \\
\hline Timing + Annual & 6 & 0.84 & 2.06 & 2.02 & 1.77 \\
\hline Water + Annual & 3 & $3.02 *$ & 0.32 & 0.87 & $5.32 * *$ \\
\hline Timing + Water + Annual & 6 & 0.66 & 0.33 & 1.80 & $2.77 *$ \\
\hline Perennial seeding rate (Perennial) & 3 & $17.30 * *$ & 1.19 & 1.11 & 0.56 \\
\hline Timing + Perennial & 6 & 0.84 & 0.81 & 1.38 & 1.43 \\
\hline Water + Perennial & 3 & 1.00 & 1.32 & 1.41 & 0.30 \\
\hline Timing + Water + Perennial & 6 & 1.35 & 1.44 & 0.46 & 0.79 \\
\hline Annual + Perennial & 9 & 1.01 & 0.87 & 0.68 & 0.75 \\
\hline Timing + Annual + Perennial & 18 & 1.37 & 1.13 & 0.87 & 1.53 \\
\hline Water + Annual + Perennial & 9 & 0.42 & 1.28 & 1.30 & 0.82 \\
\hline Timing + Water + Annual + Perennial & 18 & 1.35 & 1.20 & 0.59 & 1.35 \\
\hline
\end{tabular}

$* P \leq 0.05$

$* * P \leq 0.01$

$P=0.001)$. Annual grass density was similar among all treatments when 150 annual grass seeds $\cdot \mathrm{m}^{-2}$ were seeded (Fig. $2 \mathrm{a}-\mathrm{d}$ ). Seeding perennial grasses in autumn produced higher annual grass density than spring or seasonally split perennial grass seeding (Fig. $2 \mathrm{f}-\mathrm{h}, \mathrm{j}-\mathrm{p}$; $\left.F_{2,48}=16.46, P<0.001\right)$. Adding water yielded higher annual grass density (Fig. $2 \mathrm{f}-\mathrm{h}$, $\left.\mathrm{j}-\mathrm{p} ; F_{1,12}=10.11, P=0.008\right)$. Across all seeding treatments, annual grasses had the greatest increase in seedling density from late March to early April, after which, seedling density remained fairly constant (Fig. $2 \mathrm{f}-\mathrm{h}, \mathrm{j}-\mathrm{p} ; F_{5,12}$ $=38.33, P<0.001)$.

\section{Final Seedling Density and Biomass}

Final perennial grass density in 2013 was 2 plants $\cdot \mathrm{m}^{-2}$ higher when water was added (3.44 plants $\cdot \mathrm{m}^{-2}$, SE 0.26) compared to ambient water plots $\left(1.47\right.$ plants $\cdot \mathrm{m}^{-2}$, SE 0.26 ; Table 1; $P<0.001)$. Seasonally split perennial grass seeding produced the highest final perennial grass density (3.60 plants $\cdot \mathrm{m}^{-2}$, SE 0.31 ), followed by seeding in spring (2.11 plants $\cdot \mathrm{m}^{-2}$, SE 0.31 ) and seeding in autumn (1.66 plants $\cdot \mathrm{m}^{-2}$, SE 0.31; Table $1 ; P<0.001$ ). Perennial grass seedling densities were highest when annual grass seeding rates were low and perennial grass seeding rates were high (Table 1; $P<0.001$ ). Similarly, higher perennial grass seeding rates produced higher perennial seedling density; when perennial grass seeding rate was 150 seeds $\cdot \mathrm{m}^{-2}$, perennial grass density averaged approximately 1 plant $\cdot \mathrm{m}^{-2}$, but adding 3500 seeds $\cdot \mathrm{m}^{-2}$ produced about 4 plants $\cdot \mathrm{m}^{-2}$ (Fig. 3A; $P<$ $0.001)$. Perennial grass density was higher in watered plots, especially at low annual grass seeding rates (Fig. 3B; $P=0.031$ ). In addition, when water was added, perennial grass density was about 6 plants $\cdot \mathrm{m}^{-2}$ when annual grass seeding rate was 150 seeds $\cdot \mathrm{m}^{-2}$, but perennial grass density was $2-3$ plants $\cdot \mathrm{m}^{-2}$ at all other annual grass seeding rates (Fig. 3B). Adding water produced the highest perennial grass density when perennial grass seeding was seasonally split, followed by seeding in spring (Fig. 3C; $P=0.040$ ). However, when water was not added, perennial grass density did not differ by seeding time (Fig. 3C).

Pooled across seeding rates and watering treatments, seeding perennial grasses in autumn and spring produced the highest perennial grass biomass $\left(0.170 \mathrm{~g} \cdot\right.$ plant $^{-1}$, SE 0.033), followed by seeding in spring $\left(0.063 \mathrm{~g} \cdot\right.$ plant $^{-1}$, SE 0.033$)$ and autumn $\left(0.040 \mathrm{~g} \cdot\right.$ plant $^{-1}$, SE 0.033; Table 1; $P=$ $0.005)$. When annual grass seeding rates were low, perennial grass biomass was higher than the 3 highest annual grass seeding rates (Table 1; $P=0.002$ ). Consequently, at low annual grass seeding rates, splitting perennial grass seedings produced marginally higher perennial grass densities (Fig. 4; $P=0.060$ ). 

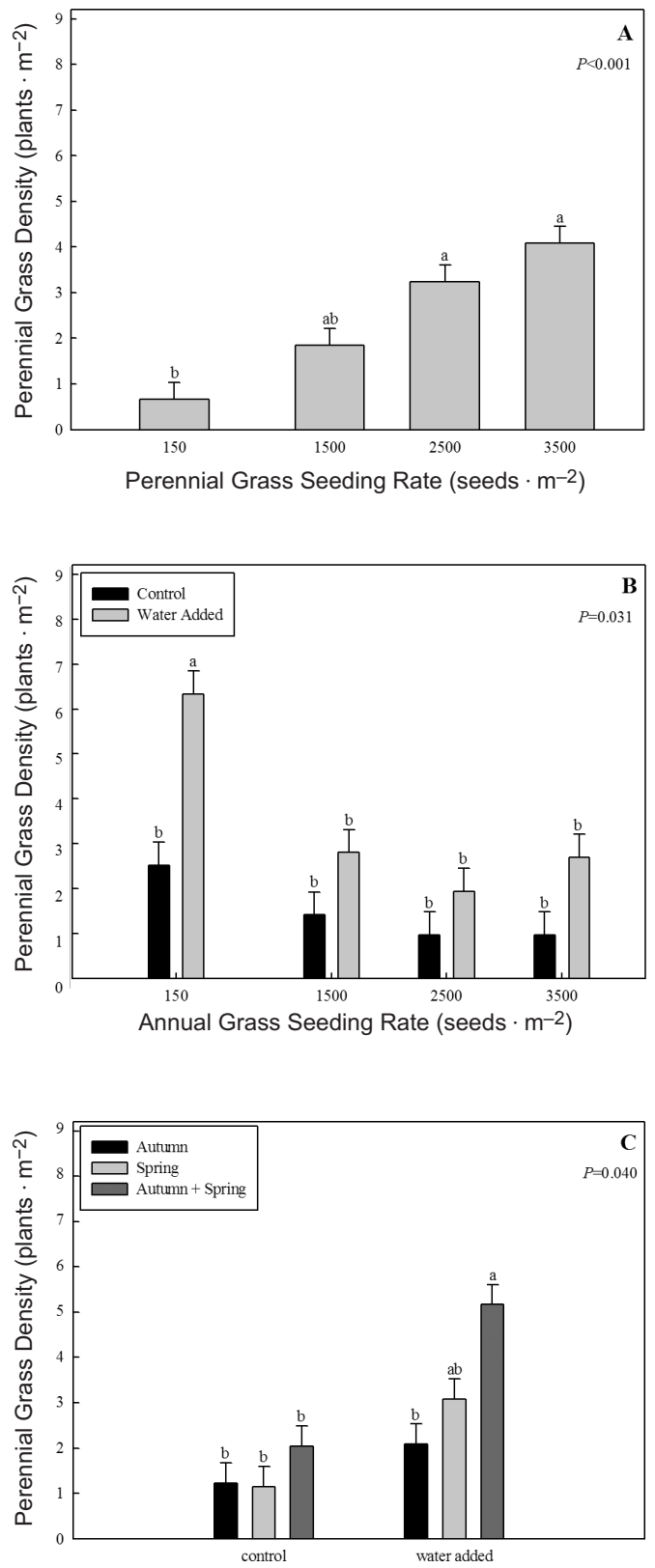

Water Availability

Fig. 3. A, Final density of perennial grasses (plants $\cdot \mathrm{m}^{-2}$ ) in the second growing season (LS means $\pm 1 \mathrm{SE}$ ) by perennial grass seeding rate $(P<0.001 ; n=288)$; $\mathbf{B}$, water availability by annual grass seeding rate interaction $(P=$ 0.031; $n=288)$; , water availability and seeding time interaction $(P=0.040 ; n=288)$.

Higher annual grass seeding rates yielded higher final annual grass density (Table $1 ; P<$ 0.001). However, the percent establishment of

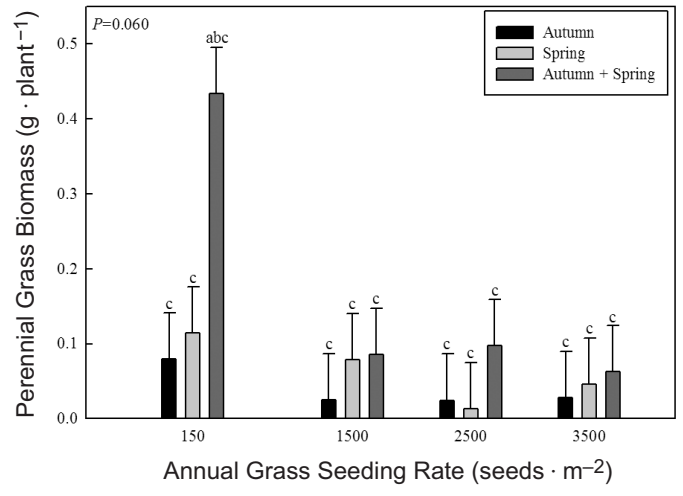

Fig. 4. Perennial plant biomass $\left(g \cdot\right.$ plant $\left.^{-1}\right)$ in the second growing season (LS means $\pm 1 \mathrm{SE}$ ) by seeding time and annual grass propagule pressure interaction $(P=0.060$; $n=288)$.

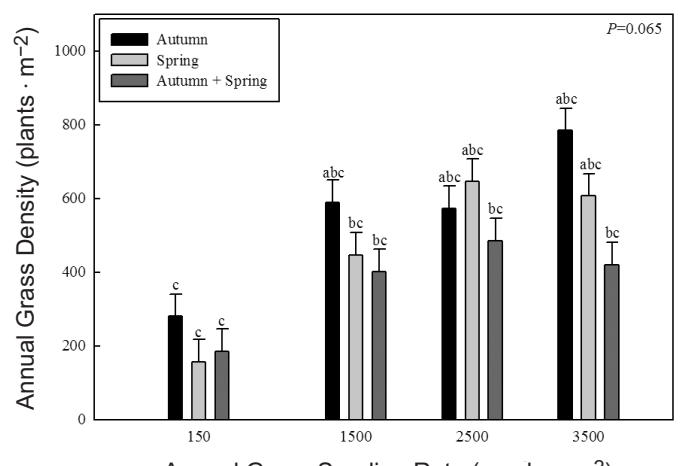

Fig. 5. Final annual plant density (plants $\cdot \mathrm{m}^{-2}$ ) in the second growing season (LS means $\pm 1 \mathrm{SE}$ ) by seeding time by annual grass propagule pressure interaction $(P=$ $0.065 ; n=288$ ).

annual grasses decreased when annual grass seeding rates increased. For example, when 150 annual grass seeds $\cdot \mathrm{m}^{-2}$ were seeded, annual grass density was about 200 plants . $\mathrm{m}^{-2}$ (SE 38.67), but seeding 3500 annual grass seeds $\cdot \mathrm{m}^{-2}$ only produced about 600 plants . $\mathrm{m}^{-2}$ (SE 38.67) $(P<0.001)$. Annual grass density was about $200-400$ plants $\cdot \mathrm{m}^{-2}$ higher at the 3 highest annual grass seeding rates within a seeding time as compared to when only 150 annual grass seeds $\cdot \mathrm{m}^{-2}$ were added (Fig. 5; $P=0.065)$. When annual grass seeding rates were 1500 or 3500 seeds $\cdot \mathrm{m}^{-2}$, annual grass density was highest when perennial grasses were seeded in autumn $(P<0.001)$. Annual grass density was also marginally higher when 

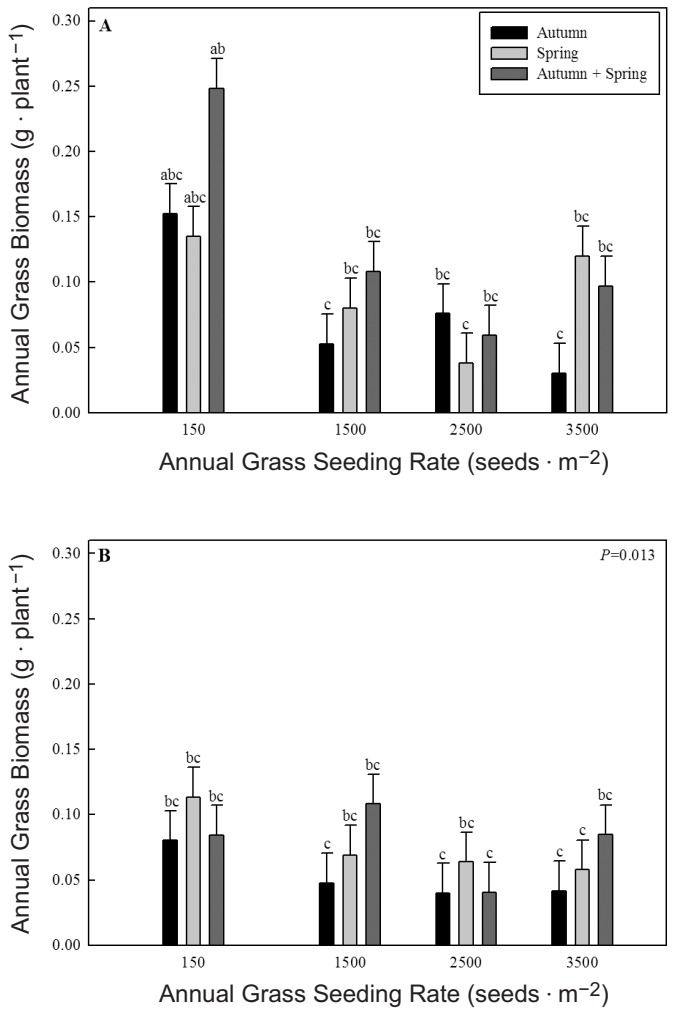

Fig. 6. Annual plant biomass $\left(\mathrm{g} \cdot \mathrm{plant}^{-1}\right)$ in the second growing season (LS means $\pm 1 \mathrm{SE}$ ) by the interaction between water availability, seeding time, and annual grass propagule pressure $(P=0.013 ; n=288)$ : A, no-water treatment; $\mathbf{B}$, water-added treatment.

3500 annual grass seeds $\cdot \mathrm{m}^{-2}$ were added and perennial grasses were seeded in autumn $(P=$ $0.065)$. Seeding perennial grasses in spring produced higher annual grass density than seasonally split seeding when annual grass seeding rate were 2500 or 3500 seeds $\cdot \mathrm{m}^{-2}$.

Annual grass biomass was highest when perennial grasses were seeded in a seasonally split regime $\left(0.104 \mathrm{~g} \cdot\right.$ plant $^{-1}$, SE 0.013$)$, followed by spring seeding $\left(0.085 \mathrm{~g} \cdot\right.$ plant $^{-1}, \mathrm{SE}$ $0.013)$ and autumn seeding $\left(0.065 \mathrm{~g} \cdot\right.$ plant $^{-1}$, SE 0.013; Table 1). Annual grass biomass was higher when water was added and the density of annual grasses did not differ by annual grass seeding rates (Table 1). In ambient water conditions, seeding 150 annual grass seeds $\cdot \mathrm{m}^{-2}$ produced higher annual grass biomass, especially when seeding occurred in autumn and spring (Fig. 6; $P=0.013$ ). High annual grass seeding rates produced lower individual annual plant biomass because annual grass biomass was $0.135 \mathrm{~g} \cdot$ plant $^{-1}$ (SE 0.014) when 150 annual seeds $\cdot \mathrm{m}^{-2}$ were added and only $0.07 \mathrm{~g} \cdot$ plant $^{-1}($ SE 0.014$)$ when 3500 annual grass seeds $\cdot \mathrm{m}^{-2}$ were added $(P<0.001$; post hoc slice).

\section{Discussion}

\section{Seedling Density}

In this study, annual grasses began growth 2 weeks earlier and emerged at 2.5 times the rate of perennial grasses. Annual grasses benefit from growing quickly because they are able to access realized niches and soil resources before perennials begin growth (Orloff et al. 2013), thereby avoiding temporal stressors due to resource limitations (Montoya et al. 2012). In addition, because arid regions like the shrubsteppe are limited by the number of realized niches, or safe-sites (Aicher et al. 2011), the early and high growth rates of annual grasses benefit further growth and development of annual grasses, especially compared to seeded perennial grasses (Abraham et al. 2009).

In support of our hypotheses, perennial grass seedling density was highest when perennial grass seeding was evenly split between autumn and spring (Table 1). When seedings are delayed until spring, the likelihood of a seed finding the realized niche may have increased because freezing temperatures can augment seed mortality in autumn seedings and thus increase safe-sites for spring seeds (Boyd and Lemos 2013). For example, James et al. (2011) identified that winter mortality in shrubsteppe can affect about $90 \%$ of graminoid seedlings between the germination and emergence life history stages. In a previous study, we also found that when annual grasses were seeded in the spring, annual grass density and biomass were higher than when annual grasses were seeded in autumn (Schantz et al. 2015). In addition, although annual grasses generally begin growing in autumn, they are opportunistic and can begin growth when weather becomes favorable (DeLucia et al. 1989). Thus, increasing perennial grass seeding frequency to fall and spring should increase the likelihood that perennial grass seeds find the realized niche in regions where annual grass interference is high.

Annual grass propagule pressure can interfere with the recruitment of perennial grasses, 
especially in areas where annual grass density is high (DiVittorio et al. 2007). Similarly, in support of our hypotheses, we found that the density of emerging perennial grass coleoptiles was highest when annual grass propagule pressure was 150 seeds $\cdot \mathrm{m}^{-2}$, when perennial grass propagule pressure was 2500 seeds $\cdot \mathrm{m}^{-2}$ or higher, and when perennial grass seeding occurred in autumn and spring (Fig. $\mathrm{lb}-\mathrm{d}, \mathrm{f}-\mathrm{h}$, $\mathrm{j}-\mathrm{l}, \mathrm{n}-\mathrm{p}$; Aicher et al. 2011). In addition, perennial grass density was also high when perennial grasses were seeded in spring, but only when annual grass propagule pressure was 150 seeds $\cdot \mathrm{m}^{-2}$. Similarly, Mazzola et al. (2011) also found that when invasive annual grass density is high, seeded perennial grass density will be low. In areas dominated by annual grasses, propagule pressure can exceed 10,000 seeds $\cdot \mathrm{m}^{-2}$ (Humphrey and Schupp 2001), and annual grasses can preempt safe-sites from developing perennial grasses and thereby reduce perennial grass density (DiVittorio et al. 2007). This is especially apparent when annual grass propagule pressure is high (Orrock and Christopher 2010). However, reseeding manuals for government agencies generally suggest that perennial grass seeding rates of approximately 650 seeds $\cdot \mathrm{m}^{-2}$ are appropriate for establishing a successful seeding in similar shrubsteppe ecosystems if herbicides are used to reduce the density of annual grasses prior to seeding (Benson et al. 2011). Preemergent herbicides like imazapic (Plateau ${ }^{\circledR}$ ) and sulfonylurea herbicides are effective at reducing annual grass density (Monaco et al. 2005, Kyser et al. 2007), and Brisbin et al. (2013) found that imazapic can reduce some annual grass propagule pressure. However, it is unlikely that managers will be able to effectively reduce annual grass propagule pressure to 1500 seeds $\cdot \mathrm{m}^{-2}$ or less in areas where residual annual grass propagule pressure is 10,000 seeds $\cdot \mathrm{m}^{-2}$ or higher using only preemergent herbicides. For example, Brisbin et al. (2013) acknowledge that imazapic only reduced the seed bank by approximately $50 \%$ in the first growing season. In addition, the effects of preemergent herbicides are short lived, generally only lasting one growing season (Monaco et al. 2005, Kyser et al. 2007), and the residual effects of herbicides can reduce seeded perennial grass emergence (Hirsch et al. 2012). Consequently, for areas heavily infested with annual grasses, a combination of targeted management inputs, such as burning in combination with preemergent herbicides that can reduce the existing annual grass propagule pressure to 1500 seeds $\cdot \mathrm{m}^{-2}$ or lower, should be employed prior to seeding and recommended seeding rates of native perennial grasses should likely be higher than 650 seeds $\cdot \mathrm{m}^{-2}$.

Higher water availability during seedling emergence should increase seedling growth, because where water availability is high, soil resource availability is also high and stress for resources is low (Everard et al. 2010). Even though watering treatment did not appreciably increase monitored volumetric soil moisture contents (Appendix 3), it did increase perennial grass seedling density, especially when seeding of perennial grasses was split between autumn and spring, as we hypothesized. Seeding Great Basin ecosystems in the spring can be risky because site access can be limited by wet soils from winter snowmelt and wet spring conditions (Fischer and Turner 1978). The first year following seeding, our study site received lower-than-average precipitation. Increasing water availability likely increased perennial grass seedling emergence rates, especially when these species were seeded in the spring. In addition, even small differences in volumetric soil moisture can result in dramatic differences in soil matrix potential, which can strongly affect seed germination and establishment (Evans and Etherington 1991). Thus, while our volumetric soil water content measurements missed the enhancement of added water, the plants did not. Consequently, when perennial grasses are seeded in spring or seasonally split between autumn and spring, perennial grass density will likely be higher because of higher water availability.

\section{Seedling Density and Biomass after Two Growing Seasons}

Our findings support our hypothesis that perennial grass density and biomass would be highest when a sufficient amount of perennial grasses were seeded in autumn and spring. Because perennial grasses are better competitors for resources than annual grasses, once they are established (Steers et al. 2011), it is possible when perennial grasses emerge prior to annual grasses that they will either coexist with or outcompete annual grasses. In addition, our finding that seeding annual and perennial grasses in autumn produced low perennial and 
high annual grass densities suggests that seeding perennial grasses in autumn will not facilitate native perennial grass establishment. Low perennial grass establishment when perennial grasses are seeded in autumn may be because perennial grass development is slower than annual grass development. Additionally, perennial grasses rarely reach reproductive maturity and become self-sustaining in the first growing season, whereas annual grasses typically produce copious amounts of seed within the first growing season (Sheley and James 2014). Thus, providing perennial grasses a priority seeding effect by delaying seeding until spring can increase perennial grass densities because natives that establish early can acquire the resources necessary for growth and development (Orloff et al. 2013).

Increasing perennial grass propagule pressure and seeding frequency by seasonally splitting perennial grass seeding yielded higher perennial grass density. Yet, adding more than 2500 perennial grass seeds $\cdot \mathrm{m}^{-2}$ did not increase perennial grass density. This may be because a seed likely had few safesites, and increasing the perennial grass seeding rate, in combination with increasing the seeding frequency, increased the probability that a seed found a safe-site. However, this effect only lasted up to the point of safe-site saturation, which was approximately 2500 perennial grass seeds $\cdot \mathrm{m}^{-2}$ for this region (Clark et al. 2007). Similarly, when perennial grasses were seeded in autumn and spring, the low perennial grass biomass when annual grass seeding rates were 1500 seeds $\cdot \mathrm{m}^{-2}$ or higher suggests that annual grass interference is high when annual grass propagule pressure exceeds 1500 seeds $\cdot \mathrm{m}^{-2}$. Consequently, there appears to be a threshold between 150 and 1500 annual grass seeds $\cdot \mathrm{m}^{-2}$, where annual grass interference will reduce perennial grass density, regardless of when perennial grass seeding occurs.

Consistent with our hypotheses, increasing water availability in the first growing season increased perennial grass density and biomass in the second growing season. It appears that initial growing conditions in the first growing season affected the growth of perennial grasses in the second growing season because environmental conditions during early plant growth can affect plant fitness in later growing seasons (Everard et al. 2010). However, because adding water only increased perennial grass density when annual grass density was lowest and adding water increased the biomass of annual grasses, annual grass interference for soil resources will likely limit perennial grass density when annual grass seeding rates exceed 150 seeds $\cdot \mathrm{m}^{-2}$ (Fig. 3B).

Annual and perennial grass density and biomass were lower in the second growing season when initial annual grass propagule pressure was high. This may be due to density dependence, because where annual grasses dominate, density dependence (e.g., regulation of population growth rates by population density) is common (Goldberg et al. 2001). In addition, intra- and interspecific competition for resources during the initial growing season likely affects plant community structure in the second growing season (Sheley and James 2014). Alternatively, higher perennial grass seeding rates had a neutral effect on both annual and perennial grass biomass, possibly because of low perennial grass density. Because annual grasses quickly develop into reproductive adults (Kulpa et al. 2012), whereas perennial bunchgrasses slowly develop from seed and rarely become reproductive until the second growing season (Montoya et al. 2012), the competitive relationships among these seedlings favor annual grass production, especially at early growth stages (Mazzola et al. 2011). Because of these relationships, it seems reasonable that changing native perennial grass seeding timing will facilitate the establishment of these later-developing plant species as it minimizes the temporal overlap, and thereby opens a gap for desirable seedling development.

\section{Caveats}

In general, perennial grasses had low establishment rates at this site. Low perennial grass recruitment is typical in arid Great Basin ecosystems, especially on annual grassdominated ecosystems (Abella and Smith 2013). Using local seed sources may have improved results (Leger 2008, Enright et al. 2014). In addition, conducting this experiment in an area that was not tilled and/or previously invaded by annual grasses would have likely yielded higher perennial grass recovery (Morris et al. 2013). Although we attempted to control the annual grass seed bank by tilling and using glyphosate, because the field was infested 
with medusahead prior to seeding, we were unable to eliminate all live annual grass seeds in the seed bank and background annual grass growth was as high as 53 plants $\cdot \mathrm{m}^{-2}$ in unseeded (blank) plots. This is why at our lowest annual grass seeding rate of 150 seeds $\cdot \mathrm{m}^{-2}$, we counted more emerged annual grass seedlings than were seeded (approximately 200 seeds $\cdot \mathrm{m}^{-2}$ ). However, we carefully chose this study area because of its characteristic climate, soils, and annual grass dominance that are typical of problem areas in need of restoration. Thus, regardless of seeding densities, weather and the degree to which the annual grass seed bank is reduced will always have a significant effect on outcomes (Roundy et al. 2007, Allen et al. 2008), and in priority areas, multiple interventions will be required (Hirsch-Schantz et al. 2014).

\section{Conclusions and Management Implications}

Modifying the timing and frequency of perennial grass seed dispersal can increase perennial grass recruitment into annual grassdominated ecosystems, especially when water is abundant. In this study, we found that increasing perennial grass seeding frequency to autumn and spring or delaying perennial grass seeding until spring produced higher perennial grass density and biomass than seeding in autumn. Increasing perennial grass seeding rates also increased perennial grass density and biomass, especially when seeding frequency and water availability were high. However, there was a threshold between 150 and 1500 annual grass seeds $\cdot \mathrm{m}^{-2}$, where regardless of seeding strategy, perennial grass density and biomass were low. Higher water availability increased perennial grass establishment, but only when annual grass propagule pressure was low. This study confirms that modifying dispersal dynamics can increase perennial grass recruitment in annual grass-dominated regions. However, because high annual grass propagule pressure limits perennial grass density and biomass, perennial grass establishment will depend upon existing annual grass propagule pressure.

Based on our results, we suggest a few tools and strategies for increasing perennial grass recruitment to these degraded rangelands. (1) Increasing perennial grass propagule pressure to at least 2500 seeds $\cdot \mathrm{m}^{-2}$ will likely yield higher perennial grass density following seed- ing. (2) Reducing the annual grass seed bank prior to seeding using preemergent herbicides (e.g., imazapic or sulfonylureas) can reduce annual grass interference by decreasing the annual grass propagule pressure (Monaco and Creech 2004, Nyamai et al. 2011). (3) Increasing perennial grass seeding frequency or delaying perennial grass seeding until spring should also increase the likelihood that a seed reaches a safe-site. As previously mentioned, managers should be cautious when seeding after herbicide application, because herbicides can have residual effects on perennial grass establishment (Hirsch et al. 2012). In addition, if annual grass propagule pressure is higher than 1500 annual grass seeds $\cdot \mathrm{m}^{-2}$, an ecological threshold has likely been crossed such that seeding perennial grasses into these degraded rangelands will be unsuccessful, regardless of herbicide application or perennial grass seeding strategy.

\section{ACKNOWLEDGMENTS}

We thank Brett Bingham and Anna Masterson for field and laboratory assistance. We also thank Dr. Kirk Reinhart, Dr. Michael Borman, Dr. Paul Doescher, Mrs. Diona Austill, and any anonymous reviewers for their reviews and comments. This work was funded by the USDA-ARS EBIPM research project.

\section{Literature Cited}

Abella, S.R., And S.D. Smith. 2013. Annual-perennial plant relationships and species selection for desert restoration. Journal of Arid Land 5:298-309.

Abraham, J.K., J.D. Corbin, and C.M. D’Antonio. 2009. California native and exotic perennial grasses differ in their response to soil nitrogen, exotic annual grass density, and order of emergence. Plant Ecology 201: 445-456.

Aicher, R.J., L. Larios, and K.N. Suding. 2011. Seed supply, recruitment, and assembly: quantifying relative seed and establishment limitation in a plant community context. American Naturalist 178:464-477.

Allen, E.A., J.C. Chambers, and R.S. NowaK. 2008. Effects of a spring prescribed burn on the soil seed bank in sagebrush steppe exhibiting pinyon-juniper expansion. Western North American Naturalist 68: 265-277.

Benson, J.E., R.T. Tveten, M.G. Asher, and P.W. DunWIDDIE. 2011. Shrub-steppe and grassland restoration manual for the Columbia River Basin. Washington Department of Fish and Wildlife.

Boyd, C.S., AND J.A. Lemos. 2013. Freezing stress influences emergence of germinated perennial grass seeds. Rangeland Ecology and Management 66: 136-142. 
Brisbin, H., A. Thode, M. Brooks, and K. Weber. 2013. Soil seed bank responses to postfire herbicide and native seeding treatments designed to control Bromus tectorum in a pinyon-juniper woodland at Zion National Park, USA. Invasive Plant Science and Management 6:118-129.

Clark, C.J., J.R. Poulsen, D.J. Levey, and C.W. OsenBERG. 2007. Are plant populations seed limited? A critique and meta-analysis of seed addition experiments. American Naturalist 170:128-142.

Cox, R.D., AND E.B. ALlEN. 2008. Stability of exotic annual grasses following restoration efforts in southern California coastal sage scrub. Journal of Applied Ecology 45:495-504.

DeLucia, E.H., W.H. Schlesinger, and W.D. Billings. 1989. Edaphic limitations to growth and photosynthesis in Sierran and Great Basin vegetation. Oecologia 78:184-190.

DiVittorio, C.T., J.D. Corbin, and C.M. D’Antonio. 2007. Spatial and temporal patterns of seed dispersal: an important determinant of grassland invasion. Ecological Applications 17:311-316.

Doll, J.E., K.A. Haubensak, E.L. Bouressa, and R.D. JACKSON. 2011. Testing disturbance, seeding time, and soil amendments for establishing native warmseason grasses in non-native cool-season pasture. Restoration Ecology 19:1-8.

Enright, N.J., J.B. Fontaine, B.B. Lamont, B.P. Miller, AND V.C. WestcotT. 2014. Resistance and resilience to changing climate and fire regime depend on plant functional traits. Journal of Ecology 102: $1572-1581$.

Evans, C.E., And J.R. Etherington. 1991. The effect of soil-water potential on seedling growth of some British plants. New Phytologist 118:571-579.

Evans, R.A., AND J.A. Young. 1972. Microsite requirements for establishment of annual rangeland weeds. Weed Science 20:350-356.

Everard, K., E.W. Seabloom, W.S. Harpole, and C. DE MAZANCOURT. 2010. Plant water use affects competition for nitrogen: why drought favors invasive species in California. American Naturalist 175:85-97.

Fischer, R.A., AND N.C. TuRNER. 1978. Plant productivity in arid and semi-arid zones. Annual Review of Plant Physiology and Plant Molecular Biology 29: 277-317.

Goldberg, D.E., R. Turkington, L. Olsvig-Whittaker, AND A.R. Dyer. 2001. Density dependence in an annual plant community: variation among life history stages. Ecological Monographs 71:423-446.

GrubB, P.J. 1977. Maintenance of species-richness in plant communities-importance of regeneration niche. Biological Reviews of the Cambridge Philosophical Society 52:107-145.

Hirsch, M.C., T.A. Monaco, C.A. Call, and C.V. Ransom. 2012. Comparison of herbicides for reducing annual grass emergence in two Great Basin soils. Rangeland Ecology and Management 65:66-75.

Hirsch-Schantz, M.C., T.A. Monaco, C.A. Call, and R. SHELEY. 2014. Large-scale downy brome treatments alter plant-soil relationships to facilitate perennial grasses in salt desert shrublands. Rangeland Ecology and Management 67:255-265.

Humphrey, L.D., AND E.W. Schupp. 2001. Seed banks of Bromus tectorum-dominated communities in the Great Basin. Western North American Naturalist 61:85-92.
James, J.J., M.J. Rinella, and T. SvejCar. 2012. Grass seedling demography and sagebrush steppe restoration. Rangeland Ecology and Management 65:409-417.

James, J.J., T.J. SvejCar, and M.J. Rinella. 2011. Demographic processes limiting seedling recruitment in arid grassland restoration. Journal of Applied Ecology 48:961-969.

Kulpa, S.M., E.A. Leger, E.K. Espeland, and E.M. GoERGEN. 2012. Postfire seeding and plant community recovery in the Great Basin. Rangeland Ecology and Management 65:171-181.

Kyser, G.B., J.M. DiTomaso, M.P. Doran, S.B. Orloff, R.G. Wilson, D.L. LanCaster, D.F. Lile, and M.L. Porath. 2007. Control of medusahead (Taeniatherum caput-medusae) and other annual grasses with imazapic. Weed Technology 21:66-75.

LEgER, E.A. 2008. The adaptive value of remnant native plants in invaded communities: an example from the Great Basin. Ecological Applications 18: 1226-1235.

Mazzola, M.B., J.C. Chambers, R.R. Blank, D.A. Pyke, E.W. Schupp, K.G. Allcock, P.S. Doescher, and R.S. NOWAK. 2011. Effects of resource availability and propagule supply on native species recruitment in sagebrush ecosystems invaded by Bromus tectorum. Biological Invasions 13:513-526.

Monaco, T.A., and J.E. Creech. 2004. Sulfosulfuron effects on growth and photosynthesis of 15 range grasses. Journal of Range Management 57:490-496.

Monaco, T.A., T.M. Osmond, and S.A. Dewey. 2005. Medusahead control with fall- and spring-applied herbicides on northern Utah foothills. Weed Technology 19:653-658.

Montoya, D., L. Rogers, and J. Memmott. 2012. Emerging perspectives in the restoration of biodiversitybased ecosystem services. Trends in Ecology and Evolution 27:666-672.

Morris, L.R., T.A. Monaco, R. Blank, and R.L. Sheley. 2013. Long-term redevelopment of resource islands in shrublands of the Great Basin, USA. Ecosphere $4(1): 12$.

Nyamai, P.A., T.S. Prather, and J.M. Wallace. 2011. Evaluating restoration methods across a range of plant communities dominated by invasive annual grasses to native perennial grasses. Invasive Plant Science and Management 4:306-316.

Orloff, N.L., J.M. Mangold, and F.D. Menalled. 2013. Role of size and nitrogen in competition between annual and perennial grasses. Invasive Plant Science and Management 6:87-98.

Orrock, J.L., And C.C. Christopher. 2010. Density of intraspecific competitors determines the occurrence and benefits of accelerated germination. American Journal of Botany 97:694-699.

Radosevich, S.R. 1987. Methods to study interactions among crops and weeds. Weed Technology 1:190-198.

Roundy, B.A., S.P. Hardegree, J.C. Chambers, and A. Whittaker. 2007. Prediction of cheatgrass field germination potential using wet thermal accumulation. Rangeland Ecology and Management 60:613-623.

SAS. 2012. SAS 9.2 [software]. SAS Institute, Cary, NC.

SatterthWaite, W.H. 2007. The importance of dispersal in determining seed versus safe site limitation of plant populations. Plant Ecology 193:113-130.

Schabenberger, O. 2013. Slicing interactions in SAS. UCLA Statistical Consulting Group, Institute for Digital Research and Education; [cited 20 March 
2013]. http://www.ats.ucla.edu/stat/sas/library/SAS Slice os.htm

Schantz, M.C., R.L. Sheley, and J.J. James. 2015. Role of propagule pressure and priority effects on seedlings during invasion of shrub-steppe. Biological Invasions 17:73-85.

Seabloom, E.W., E.T. Borer, V.L. Boucher, R.S. Burton, K.L. Cottingham, L. Goldwasser, W.K. Gram, B.E. Kendall, AND F. Micheli. 2003. Competition, seed limitation, disturbance, and reestablishment of California native annual forbs. Ecological Applications $13: 575-592$

Seastedt, T.R., AND P. PyšEk. 2011. Mechanisms of plant invasions of North American and European grasslands. Annual Review of Ecology and Systematics 42:133-153.

Sheley, R.L., AND J.J. James. 2014. Simultaneous intraspecific facilitation and interspecific competition between native and annual grasses. Journal of Arid Environments 104:80-87.

Steers, R.J., J.L. Funk, and E.B. Allen. 2011. Can resource-use traits predict native vs. exotic plant success in carbon amended soils? Ecological Applications 21:1211-1224.

[WrCC] Western Regional Climate Center. 2013. Juntura, Oregon climate. [Accessed 14 July 2013]. http://wrcc.dri.edu.

Walck, J.L., S.N. Hidayati, K.W. Dixon, K. Thompson, AND P. PoschloD. 2011. Climate change and plant regeneration from seed. Global Change Biology $17: 2145-2161$.

Received 20 January 2015 Accepted 30 September 2015

APPENDIX 1. Seeding factors and factor levels $(n=288)$

\begin{tabular}{llcr}
\hline $\begin{array}{l}\text { Perennial dispersal } \\
\text { timing }\end{array}$ & Water & $\begin{array}{c}\text { Annual grass } \\
\text { seeding rate } \\
\left(\text { seeds } \cdot \mathrm{m}^{-2}\right)\end{array}$ & $\begin{array}{c}\text { Perennial grass } \\
\text { seeding rate } \\
\left(\mathrm{seeds}^{-2} \mathrm{~m}^{-2}\right)\end{array}$ \\
\hline $\begin{array}{l}\text { Autumn (November) } \\
\text { Spring (February) }\end{array}$ & No water & 150 & 150 \\
Wplit (Nov + Feb) & Water added & 1500 & 1500 \\
& & 2500 & 2500 \\
\hline
\end{tabular}

Appendixes 2 and 3 on page 52. 

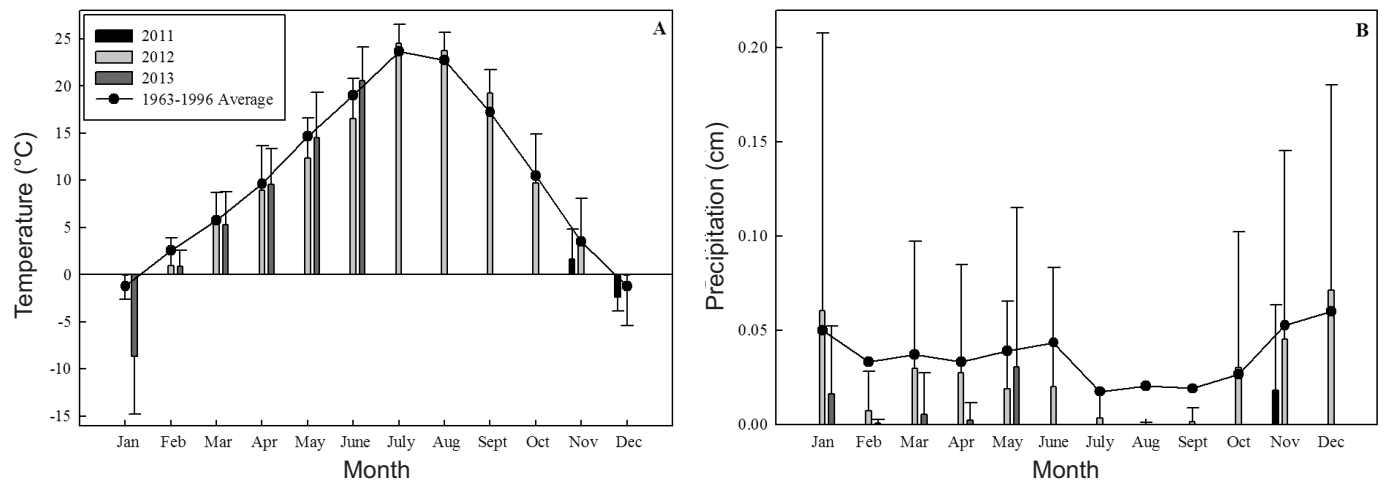

APPENDIX 2. Mean and standard deviation of climate during the sampling period (November 2011-June 2013) and the 30 -year average daily precipitation and temperature: $\mathbf{A}$, average daily temperature $\left({ }^{\circ} \mathrm{C}\right) ; \mathbf{B}$, average daily precipitation $(\mathrm{cm})$.

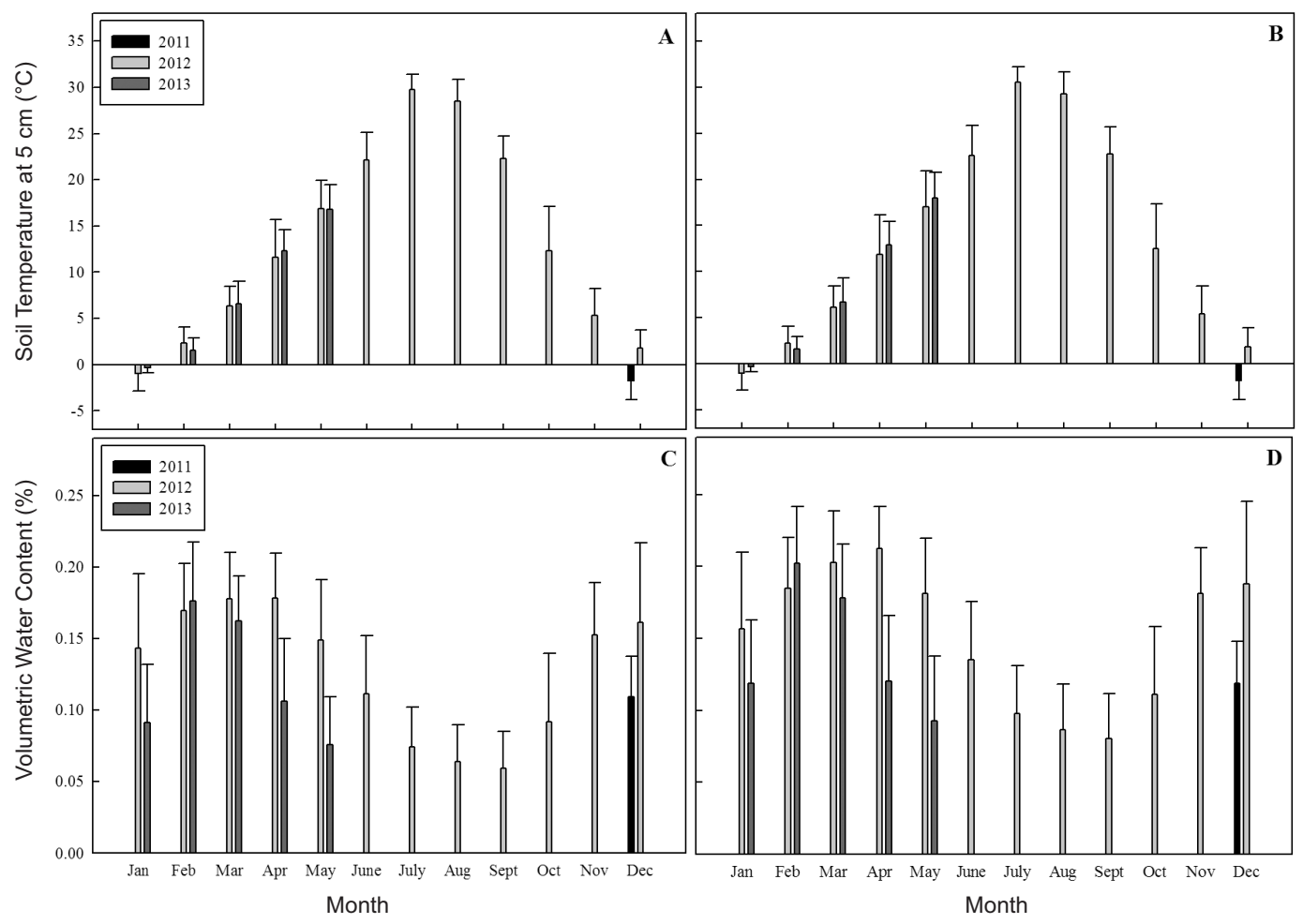

ApPendix 3. Means and standard deviation of soil temperature at $5 \mathrm{~cm}\left({ }^{\circ} \mathrm{C}\right)$ and volumetric water content at $5 \mathrm{~cm}(\%)$ measured from December 2012 to May 2013: A, soil temperature in the control (no water) treatment; B, soil temperature in the water-added treatment; $\mathbf{C}$, volumetric water content in the control treatment; $\mathbf{D}$, volumetric water content in the water-added treatment. 